\title{
Dampak Medioker di Era Jokowi-Jk terhadap Welfare State Berdasarkan UU No. 17 Tahun 2007 tentang RPJP Nasional
}

\author{
Maulida Maulaya Hubbah ${ }^{1}$
}

${ }^{1}$ Fakultas Syariah, IAIN Jember. E-mail: nenghubbah24@gmail.com

\begin{tabular}{|c|c|}
\hline Article & Abstract \\
\hline $\begin{array}{l}\text { How to cite: } \\
\text { Maulida Maulaya } \\
\text { Hubbah, 'Dampak } \\
\text { Medioker di Era } \\
\text { Pemerintahan Jokowi-Jk } \\
\text { terhadap Visi Welfare } \\
\text { State Berdasarkan } \\
\text { Undang-Undang Nomor } \\
\text { 17 Tahun 2007 tentang } \\
\text { Rencana Pembangunan } \\
\text { Jangka Panjang (RPJP) } \\
\text { Nasional' Vol. } 1 \text { No. } 3 \\
\text { Rechtenstudent Journal } \\
\text { Fakultas Syariah IAIN } \\
\text { Jember. } \\
\text { Histori artikel: } \\
\text { Submit } 2 \text { September 2020; } \\
\text { Diterima 16 November } \\
\text { 2020; Diterbitkan } 7 \\
\text { Desember 2020. } \\
\text { ISSN: } \\
\text { 2723-0406 (media cetak) }\end{array}$ & 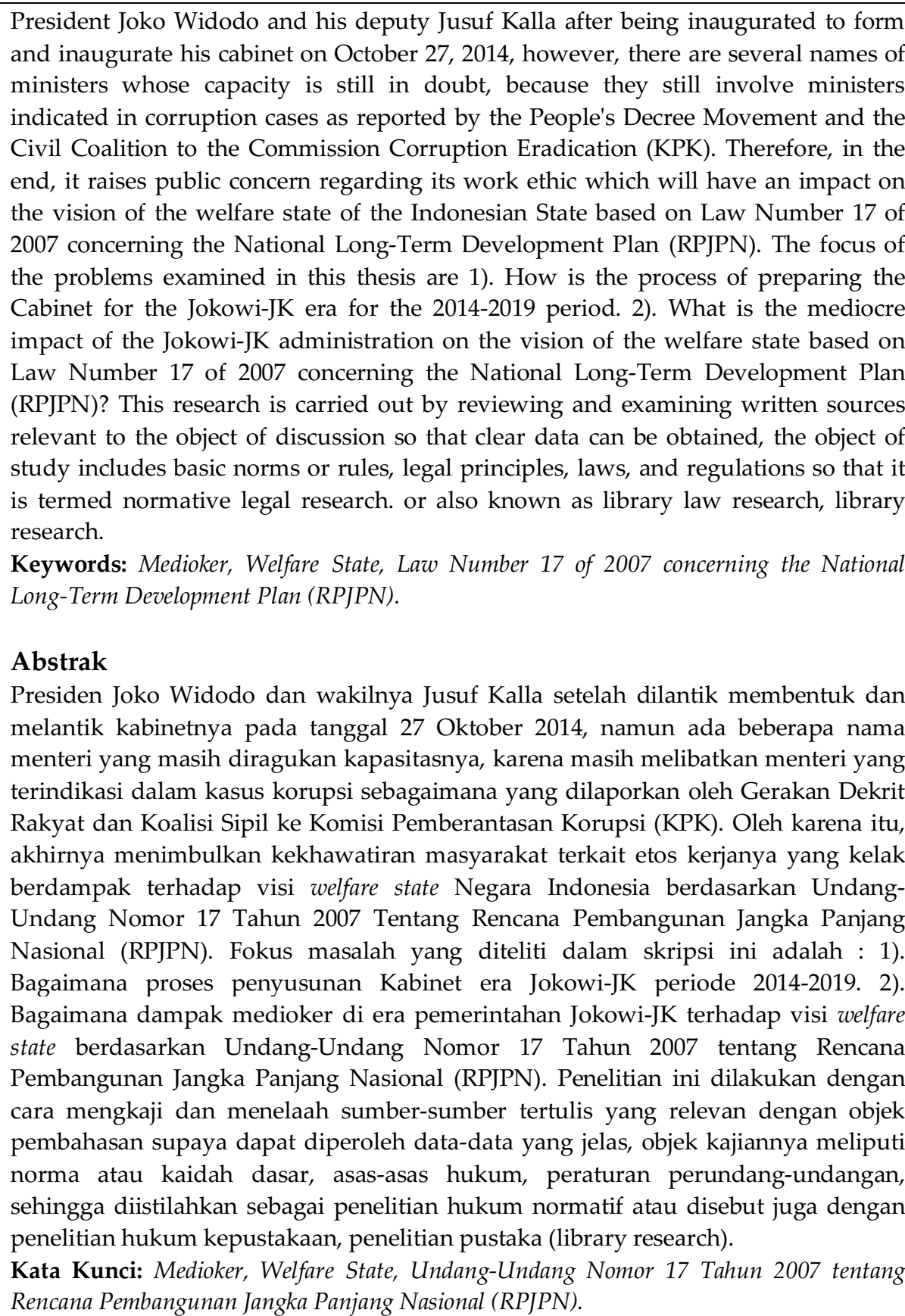 \\
\hline
\end{tabular}




\section{Pendahuluan}

Setiap berdirinya suatu negara memiliki tujuan tersendiri yang selalu berorientasi kepada kesejahteraan. Menjadi suatu negara kesejahteraan (welfare state), negara dituntut untuk bertanggungjawab terhadap kesejahteraan sosial, kesehatan, pendidikan, pelatihan skill, social security warga negaranya. Ada tiga tugas negara yang berkaitan dengan masyarakat, pertama adalah bidang pertanahan yaitu memberikan kebebasan kepada orang-orang yang melawan penyerangan dan perbudakan, meskipun memerlukan biaya besar. Kedua, melindungi setiap anggota masyarakat untuk melawan ketidakadilan atau tekanan dari anggota masyarakat lainnya atas dasar keadilan dan kewajaran melalui penyediaan keamanan dan tidak memihak. Artinya, negara kemudian bertindak untuk mencegah adanya monopoli dari private property. Ketiga, negara membangun infrastruktur seperti memelihara pekerjaan umum dan institusi masyarakat yang bermanfaat, bukan untuk keuntungan individu atau sekelompok orang. Membangun jalanan, pelabuhan, kanal dan lain sebagainya termasuk pendidikan dan kesehatan bagi masyarakat umum. ${ }^{1}$ Negara kesejahteraan sendiri memiliki pengertian suatu konsep pemerintahan ketika negara mengambil peranan penting di dalam melindungi dan mengutamakan kesejahteraan ekonomi maupun sosial warga negaranya. ${ }^{2}$ Dalam menjalankan tujuan tersebut seluruh elemen di dalam negara wajib turut serta mewujudkannya terutama para stakeholders, elemen pemerintahan memiliki peranan terpenting dalam mewujudkan cita-cita negara, sebab pemerintah sebagai tangan kanan langsung negara yang mengendalikan segala "the rule" dalam negara itu sendiri.

"The government help us, keeps people safe, and it makes sure people follow the laws"3 yang artinya pemerintah membantu kita, membuat orang aman, dan pemerintah menekankan kepada setiap orang untuk mematuhi hukum. Maka berdasarkan konsep negara hukum yang di anut negara Indonesia (supreme of law) dengan demikian, pemerintah adalah salah satu elemen yang terpenting dalam mewujudkan tercapainya welfare state sebagai cita-cita bangsa, hal ini dapat tercapai jika tata laksana pemerintahan sudah baik (good governance).

Adapun yang disebut-sebut sebagai cita-cita negara Indonesia sudah tercantum dalam pembukaan UUD 1945 alinea keempat yang berisikan tujuan nasional. Kemudian tujuan nasional ini diimplementasikan ke dalam UU No. 17 Tahun 2007 Rencana Pembangunan Jangka Panjang (RPJP) Nasional yang disusun sebagai penjabaran dari tujuan dibentuknya pemerintahan negara Indonesia ${ }^{4}$ yang berlaku selama 20 tahun sejak ditetapkan, artinya setiap hal yang tercantum di dalam Undang-Undang tersebut menentukan nasib bangsa 20 tahun ke depan. RPJP Nasional selanjutnya menjadi acuan dalam pembentukan RPJM Nasional yang dibentuk dan disusun oleh satu masa periodisasi. Berdasarkan pasal 7 UUD 1945 setelah amandemen presiden dan wakilnya memegang jabatan selama lima tahun, yang artinya pemimpin pemerintahan dan pemimpin negara yang terpilih secara demokratis mampu mengendalikan visi dan misi tujuan negara yang disusun dan diberlakukan dalam kurun waktu 5 tahun yang dicantumkan di dalam Rencana Jangka Menengah Nasional (RPJMN). Di

\footnotetext{
${ }^{1}$ Muryanto Amin, Konsep Negara Kesejahteraan Dari Waktu Ke Waktu, Jurnal Politeia /volume 3 Nomor 2, (Juli 2011), 106.

2 Inu Kencana Syafiie, Ilmu Pemerintahan, (Bandung: Mandar Maju, 2013), 65.

${ }^{3}$ Ann-Marie Kishel, What Is Goverment?, (United State: Lerner Publishing Group, 2007), 6-11.

${ }^{4}$ Pasal 4 Undang-Undang Nomor 25 Tahun 2004 Tentang Sistem Perencanaan Pembangunan Nasional, Rencana Pembangunan Jangka Panjang Nasional.
} 
era pemerintahan Jokowi-JK RPJMN masuk pada tahap RPJM Nasional III yakni tahun 20152019.

Untuk melaksanakan setiap perencanaan di dalam RPJM Nasional Jokowi-JK dibantu para kabinet yang dipilih dengan hak prerogatif seorang presiden. Kabinet-kabinet tersebut bertanggungjawab terhadap setiap sektor yang diamanahi. Namun, saat susunan kabinet di era Jokowi-JK diumumkan dan dibentuk untuk dilantik, publik (organisasi masyarakat dan masyarakat madani) selaku penyeimbang berjalannya pemerintah (check and balance) menilai pro-contra akan susunan kabinet tersebut, hal ini disebabkan karena masih melibatkan menteri yang memiliki black track record serta kemampuan medioker dalam kapasitas kinerjanya maupun integritas kepribadiannya. Hal ini begitu mengkhawatirkan masyarakat sebab kedudukan kabinet merupakan pembantu presiden yang menentukan akan terwujud tidaknya harapan bangsa.

\section{Rumusan Masalah}

Adapun rumusan masalah dalam penelitian ini adalah:

1. Bagaimana proses penyusunan Kabinet era Jokowi-JK periode 2014-2019?

2. Bagaimana dampak medioker di era pemerintahan Jokowi-JK terhadap visi welfare state berdasarkan Undang-Undang Nomor 17 Tahun 2007 tentang Rencana Pembangunan Jangka Panjang Nasional (RPJPN)?

\section{Metode Penelitian}

Jenis penelitian ini adalah penelitian pustaka (library research) yakni peneliti dengan cara mengkaji dan menelaah sumber-sumber tertulis yang terkait dengan objek pembahasan supaya dapat diperoleh data-data yang jelas, ${ }^{5}$ dengan berpijak pada berbagai literaturliteratur dan dokumen yang berkaitan dengan objek penelitian. Kemudian penelitian ini menggunakan pendekatan yang digunakan pendekatan Undang-Undang (Statute Approach) yang dilakukan dengan menelaah semua Undang-Undang dan regulasi yang bersangkut paut dengan isu hukum yang sedang ditangani. ${ }^{6}$ Seperti halnya dalam penelitian ini pendekatan Undang-Undang akan menelaah Undang-Undang Nomor 17 Tahun 2007 tentang Rencana Pembangunan Jangka Panjang (RPJP) Nasional serta Peraturan Presiden Nomor 2 tahun 2015 tentang Rencana Pembangunan Jangka Menengah Nasional Tahun 2015-2019 sebagai tolak ukur sehingga akan menemukan titik temu terhadap objek yang akan dikaji, yaitu perihal dampak medioker di era pemerintahan Jokowi-JK terhadap visi Welfare State.

Penelitian ini bersifat Yuridis normatif yaitu penelitian yang dilakukan dengan cara meneliti data sekunder saja, yang terdiri dari: bahan hukum primer, yakni terdiri dari perundang-undangan dan juga peraturan presiden. ${ }^{7}$ Bahan hukum primer dalam penelitian ini terdiri dari Undang-Udang Nomor 17 tahun 2007 tentang Rencana Pembangunan Jangka Panjang (RPJP) Nasional dan juga Peraturan Presiden Nomor 2 tahun 2015 tentang Rencana Pembangunan Jangka Menengah Nasional Tahun 2015-2019. Kemudian bahan hukum

\footnotetext{
${ }^{5}$ Soerjono Soekanto, Pengantar Penelitian Hukum, (Jakarta: UI Press, 1986), 12.

${ }^{6}$ Amiruddin \& Zainal Asikin, Pengantar Metode Penelitian Hukum, (Depok: PTGrafindo Persada, 2016), 164.

${ }^{7}$ Dyah Octorina Susanti dan A'an Efendi, Penelitian Hukum (Legal Reseach), (Jakarta: Sinar Grafika, 2014), 48.
} 
sekunder, ${ }^{8}$ merupakan bahan yang menjelaskan bahan hukum primer, seperti buku-buku ilmiah, hasil penelitian dan karya ilmiah, semua publikasi tentang hukum yang bukan merupakan dokumen-dokumen resmi. Publikasi tentang hukum meliputi buku-buku teks, kamus-kamus, ensiklopedia hukum, jurnal-jurnal hukum dan komentar atas putusan pengadilan.

Teknik pengumpulan data dalam penelitian ini berarti dengan menggunakan teknik dokumenter, yakni mengumpulkan beberapa dokumen atau naskah yang berhubungan dengan penelitian. metode dokumentasi yaitu suatu cara yang dapat dilakukan penelitian kualitatif untuk mendapatkan gambaran dari sudut pandang subjek melalui suatu media tertulis dan dokumen lainnya yang ditulis atau dibuat langsung oleh subjek yang bersangkutan. ${ }^{9}$ Kemudian karena dalam penelitian ini termasuk jenis penelitian pustaka atau library research, teknik pengumpulan bahan hukumnya disinergikan dengan metode pendekatan penelitian yang digunakan, dalam penelitian ini maka mengumpulkan bukubuku, serta naskah-naskah yang berhubungan dengan dampak medioker di era pemerintahan Jokowi-JK terhadap visi welfare state berdasarkan Undang-Undang Nomor 17 Tahun 2007 tentang Rencana Pembangunan Jangka Panjang Nasional (RPJP).

\section{Hasil dan Pembahasan}

\section{Proses Penyusunan Kabinet Kerja Jokowi-JK 2014-2019}

Ketika Presiden Ir. Jokowi Widodo dengan wakilnya Jusuf Kalla terpilih menjadi presiden Republik Indonesia melalui pemilihan secara langsung oleh rakyat dalam pemilihan presiden tahun 2014 berdasarkan Surat Keputusan Komisi Pemilihan Umum Nomor 536/Kpts/KPU/Tahun 2014 Tentang Penetapan Calon Presiden dan Calon Wakil Presiden Terpilih dalam Pemilihan Umum Presiden dan Wakil Presiden Tahun 2014, dengan perolehan 70.9997.833 suara atau 53,15\% dari total suara sah nasional.

Setelah dilantiknya presiden serta wakil presiden pada tanggal 20 Oktober 2014 JokowiJK disibukkan dengan pembentukan "Kabinet Kerja" yang terus diwarnai dengan tarik ulur, namun pada akhirnya sejak diumumkannya para kabinet Republik Indonesia tertanggal Minggu, 26 Oktober 2014 sekitar pukul 17:30 WIB oleh Presiden Joko Widodo yang didampingi wakilnya Jusuf Kalla mengumumkan Kementerian barunya di Istana Negara di hari keenam (ke-6) setelah diamanatkan selama 14 hari oleh Undang-Undang untuk menyusun kabinet ini ${ }^{10}$, sejak itu pula, tertanggal Senin, 27 Oktober 2014 nama-nama yang tercantum dalam pengumuman kemarin harinya akan dilantik dan diambil sumpahnya tepat pukul 11:30 WIB di Istana Negara. ${ }^{11} 4$ Menteri Koordinator (Menko) dan 30 Menteri Kabinet Kerja Jokowi-JK dilantik. Semua masyarakat dari berbagai kalangan kemudian berpartisipasi dalam mengamati kinerja pemerintahan Jokowi-JK serta kinerja para menterinya, dengan didukung oleh media massa yang selalu memberikan informasi sehingga masyarakat menjadi

\footnotetext{
${ }^{8}$ Ibid, 171.

${ }^{9}$ Haris Hardiansyah, Metode Penelitian Kualitatif, (Jakarta: Salemba Humanika, 2010), 143.

${ }^{10 h t t p p: / / n e w s . d e t i k . c o m / r e a d / 2014 / 10 / 26 / 174034 / 2729927 / 10 / i n i-s u s u n a n-l e n g k a p-k a b i n e t-k e r j a-j o k o w i-~}$ jk, Ini susunan lengkap Kabinet Kerja Jokowi, DetikNews. 26 Oktober 2014. Diakses Tanggal Rabu, 1 April 2020 Pulul 11:00 WIB.

${ }^{11}$ Kementerian Komunikasi dan Informatika Republik Indonesia:, Siang Ini Dilantik, Menteri Baru Langsung Ikut Sidang Kabinet Perdana, Diakses tanggal Kamis, 21 Mei 2020 Pukul 11:18 WIB.
} 
lebih mengetahui kinerja para pemimpin, ${ }^{12}$ sebab rakyat memiliki harapan besar pada pasangan presiden dan wakil presiden ini.

Dalam pengangkatan para menteri Presiden Joko Widodo mengajukan nama-nama calon menterinya kepada Pusat Pelaporan dan Analisis Transaksi Keuangan (PPATK), Komisi Pemberantasan Korupsi (KPK) serta lembaga Komisi Nasional Hak Asasi Manusia dengan harapan para menteri dalam kabinet kerjanya bersih dari catatan merah (black track record) serta menghindarkan korupsi kementerian yang sebelumnya banyak terjerat kasus korupsi. Hal ini dilakukan agar masyarakat menjadi yakin dan percaya kepada pemerintah bahwa menteri yang dipilih oleh presiden adalah sosok yang bersih dan kompeten. Akan tetapi ketika diteliti lebih mendalam perihal susunan kabinet Jokowi-JK masih melibatkan menteri yang terindikasi dalam kasus korupsi sebagaimana yang dilaporkan oleh Gerakan Dekrit Rakyat Indonesia dan Koalisi Masyarakat Sipil ke Komisi Pemberantasan Korupsi (KPK) yang mencatat beberapa nama menteri yang terindikasi kasus korupsi. Calon menteri yaitu Rini Soemarno, Menteri Pariwisata Arief Yahya, Menteri ESDM Sudirman Said, Menteri Koordinator Perekonomian Sofyan Djalil, Menteri Komunikasi Dan Informatika Rudiantara, serta Menteri Pertanian Amran Sulaiman. ${ }^{13}$

Ditinjau secara empiris bahwa, komposisi kabinet kerja terdiri dari 16 orang yang berangkat dari anggota partai politik aktif pendukung Pemerintah seperti Menteri Dalam Negeri: Tjahjo Kumolo (Parpol-PDIP), Menteri Hukum dan Ham: Yasonna H. Laoly (PDIP), Menteri Pendayagunaan Aparatur Negara: Yuddy Chrisnandi (Hanura), Menteri BUMN: Rini M Soemarno faktor kedekatan dengan Megawati (PDIP), Menteri Perindustrian: Saleh Husin (Hanura) Menteri Koordinator Pembangunan Manusia dan Kebudayaan: Puan Maharani (PDIP), Menteri Koordinator Politik, Hukum, dan Keamanan: Tedjo Edy Purdjiatno (Nasdem), Menteri Koperasi dan UMKM: AAGN Puspayoga (PDIP), Menteri Tenaga Kerja: Hanif Dhakiri (PKB), Menteri Lingkungan Hidup dan Kehutanan: Siti Nurbaya (Nasdem), Menteri Agraria dan Tata Ruang: Ferry Mursyidan Baldan (Nasdem), Menteri Sosial: Khofifah Indar Parawansa (PKB), Menteri Pemuda dan Olahraga: Imam Nahrawi (PKB), Menteri PDT dan Transmigrasi: Marwan Jafar (PKB). Sejumlah menteri yang menjadi wakil partai didominasi oleh partai pendukung pemerintah. ${ }^{14}$

Terjadi perubahan susunan kementerian dari kabinet sebelumnya pada era SBY. Perubahan tersebut di antaranya: Kementerian Pekerjaan Umum dan Kementerian Perumahan Rakyat digabung menjadi Kementerian Pekerjaan Umum dan Perumahan Rakyat. Kementerian Pariwisata dan Ekonomi Kreatif menjadi Kementerian Pariwisata. Kementerian Pendidikan dan Kebudayaan serta Kementerian Riset dan Teknologi diubah menjadi dua Kementerian, yakni Kementerian Kebudayaan dan Pendidikan Dasar dan Menengah, juga Kementerian Riset, Teknologi dan Pendidikan Tinggi. Kementerian Kehutanan dan Kementerian Lingkungan Hidup digabung menjadi Kementerian Lingkungan Hidup dan Kehutanan. Kementerian Tenaga Kerja dan Transmigrasi dan Kementerian Pembangunan

12 Istigfaro, dkk, Relasi Pembantu Presiden Dalam Kabinet Kerja Jokowi-JK, Jurnal Penelitian Hukum Volume 3 Nomor 1, (Maret 2016 ), 2.

${ }_{13}$ Mikael Lol, Politisasi Kabinet Kerja Indonesia Hebat Jokowi-JK, Jurnal Ilmu Sosial dan Ilmu Politik, Volume, 5 Nomer 1, (2016), 24.

14 Kompas. 2014. Menteri Jokowi Yang Berasal Dari Partai Politik. [online] available at (http://nasional.kompas.com/read/2014/1026/18101431/ Ini.15.Menteri. Jokowi yang .Berasal dari. Partai. Politik.) tanggal akses 10/11/2019. 
Daerah Tertinggi diubah menjadi dua Kementerian, yakni Kementerian Ketenagakerjaan dan Kementerian Desa, Pembangunan Daerah Tertinggal dan Trans-migrasi. Kementerian Koordinator Kesejahteraan Rakyat berganti menjadi Kementerian Koordinator Pembangunan Manusia dan Kebudayaan.

Kabinet kerja yang dipimpin oleh Joko Widodo yang lebih akrab disapa Jokowi mengalami perombakan hingga Jilid III, adapun perombakannya dikarenakan beberapa faktor, diantaranya disebabkan oleh adanya atau berlakunya UU No. 39 Tahun 2008, yang berisikan bahwa presiden dapat mengangkat wakil menteri pada Kementerian tertentu. Wakil menteri merupakan pejabat karier dan bukan merupakan anggota kabinet, kemudian perombakan Jilid I (2015) terjadi pada tanggal 12 Agustus 2015, presiden Joko Widodo merombak "reshuffle" susunan kabinet kerja dengan mengganti lima menteri (termaksud tiga menteri koordinator) serta sekretaris kabinet.

Adapun menteri yang diganti pada Jilid I yakni: Luhut Binsar Pandjaitan, mantan Kepala Staf Kepresidenan, menggantikan Menko Polhukam Tedjo Edhy Purdijatno. Darmin Nasution, mantan Gubernur Bank Indonesia, menjabat sebagai Menko Perekonomian menggantikan Sofyan Djalil. Rizal Ramli, mantan Menko Perekonomian era Presiden Abdurrahman Wahid, menjadi Menko Kemaritiman menggantikan Indroyono Soesilo. Thomas Lembong, mantan pejabat Badan Penyehatan Perbankan Nasional (BPPN), menjabat sebagai Menteri Perdagangan menggantikan Rachmad Gobel. Pramono Anung, menggantikan Andi Widjajanto sebagai Sekretaris Kabinet. Sofyan Djalil menggantikan Menteri Perencanaan Pembangunan Nasional/Kepala Bappenas Andrinof Chaniago.

Adapun perubahan Jilid II terjadi pada tanggal 27 Juli 2016, Jokowi selaku presiden kembali mengumumkan perombakan susunan kabinet. Hal ini difaktori adanya dua kader partai pendukung pemerintah yang baru bergabung belakangan, yakni PAN dan Partai Golkar, pergantian itu meliputi: Menteri Koordinator Politik, Hukum, dan Keamanan; Wiranto. Menteri Keuangan; Sri Mulyani. Menteri Desa, Pembangunan Daerah Tertinggal, dan Transmigrasi; Eko Putro Sanjoyo. Menteri Perhubungan; Budi Karya Sumadi. Menteri Pendidikan dan Kebudayaan; Muhadjir Effendy. Menteri Perdagangan; Enggartiasto Lukita. Menteri Perindustrian; Airlangga Hartarto. Menteri ESDM; Archandra Tahar. Menteri PAN dan RB; Asman Abnur. Menteri Kemaritiman dan Sumber Daya; Luhut Binsar Pandjaitan. Menteri Agraria dan Tata Ruang/Kepala Badan Pertanahan Nasional; Sofyan Djalil.

Salah satu kasus yang terjadi dari perombakan Jilid II kabinet Jokowi-JK pada tanggal 15 Agustus 2016, Presiden Joko Widodo memberhentikan dengan hormat Menteri ESDM Arcandra Tahar setelah sebelumnya terjadi polemik dwi kewarganegaraan dimana Arcandra telah tinggal 20 tahun di Amerika Serikat dan disangka memiliki paspor Amerika Serikat. Arcandra menjadi menteri dengan masa jabatan terpendek sepanjang sejarah Indonesia, yakni 20 hari. Presiden Jokowi kemudian menunjuk Menko Kemaritiman dan Sumber Daya Luhut Binsar Panjaitan menjadi Pelaksana Tugas Menteri ESDM hingga dilantiknya menteri definitif. ${ }^{15}$ Pada 14 Oktober 2016, Presiden Jokowi resmi melantik Ignasius Jonan sebagai Menteri ESDM dan Arcandra Tahar sebagai Wakil Menteri ESDM setelah jabatan Menteri ESDM diisi oleh pelaksana tugas selama 2 bulan.

15 Istman M.P. (15 Agustus 2016). Presiden Jokowi Berhentikan Arcandra sebagai Menteri ESDM. Tempo.com. Diakses Tanggal Selasa, 21 April 2020 Pukul 10:01 WIB. 
Belum berhenti terjadinya perombakan pada Jilid II, berikut adalah perombakan Jilid III Kabinet Kerja Jokowi-JK. Pada 17 Januari 2018, Presiden Jokowi melantik Idrus Marham sebagai Menteri Sosial menggantikan Khofifah Indar Parawansa yang maju sebagai calon Gubernur Jawa Timur pada Pemilihan Umum Gubernur Jawa Timur 2018 serta melantik Moeldoko sebagai Kepala Staf Kepresidenan menggantikan Teten Masduki.

Pada 15 Agustus 2018, Presiden Jokowi melantik Komjen Pol. Syafrudin sebagai Menteri Pendayagunaan Aparatur Negara dan Reformasi Birokrasi menggantikan Asman Abnur yang telah mengundurkan diri dari jabatannya karena Partai Amanat Nasional tidak mendukung Presiden Joko Widodo di Pilpres 2019.16 Pada 24 Agustus 2018, Presiden Jokowi melantik Agus Gumiwang Kartasasmita sebagai Menteri Sosial menggantikan Idrus Marham yang ditetapkan sebagai tersangka kasus dugaan korupsi PLTU Riau-1 yang sedang diproses oleh Komisi Pemberantasan Korupsi. ${ }^{17}$

\section{Analisis Dampak Medioker di Era Pemerintahan Jokowi-JK terhadap Visi Walfare State Berdasarkan Undang-Undang Nomor 17 tentang RPJP Nasional}

Secara konstitusi sangat jelas bahwa, presiden mempunyai otoritas dalam menetapkan kementerian, namun berdasarkan pertimbangan-pertimbangan seperti yang dimuat dalam undang-undang dasar yang dijadikan sebagai acuan utama presiden dalam menetapkan menteri, namun dalam mempertimbangkan cakupan tugas dan proporsional beban kerja belum dipertimbangkan secara baik. Pengangkatan menteri yang kapabilitasnya masih diragukan atau medioker (kualitas sedang, nilai, kemampuan atau kinerja yang rendah atau biasa-biasa), ${ }^{18}$ sehingga masyarakat khawatir akan mempunyai pengaruh negatif terhadap visi-misi pemerintahan yang diusung oleh Jokowi-JK dalam tercapainya tatanan masyarakat yang berdaulat, mandiri dan berkepribadian berlandaskan gotong royong.

Di dalam RPJM Nasional era Jokowi-JK yakni tahun 2015-2019, harapannya nawacita bukan hanya sekedar janji namun petunjuk ke mana pembangunan akan diarahkan. ${ }^{19}$ Maka selanjutnya agar cita-cita suatu negara tercapai sesuai target, pemerintah kemudian secara nasional menyusun Rencana Pembangunan Jangka Menengah Nasional (RPJMN). Di dalam masa pemerintahan Jokowi-JK RPJM Nasional lebih dikenal sebagai "NAWACITA" yakni sembilan agenda prioritas yang bertujuan untuk menyelesaikan berbagai persoalan bangsa. Nawacita tersebut kemudian dilegalitaskan dalam Peraturan Presiden Republik Indonesia Nomor 2 Tahun 2015 tentang Rencana Pembangunan Jangka Menengah Nasional Tahun 20152019. Muatan dalam RPJM Nasional harus berpedoman kepada RPJP Nasional yakni strategi pembangunan nasional, kebijakan umum, program kementerian/ lembaga dan lintas kementerian/ lembaga, kewilayahan dan lintas kewilayahan, serta kerangka ekonomi makro yang mencangkup gambaran perekonomian secara menyeluruh termasuk arah kebijakan

16 https://nasional.kompas.com/read/2018/08/14/13231311/tak-ingin-jadi-beban-presiden-jokowi-asmanabnur-ingin-mundur-dari-kabinet Diakses pada Tanggal Selasa, 21 April 2020 Pukul 10:09 WIB.

${ }^{17 h t t p s: / / n a s i o n a l . k o m p a s . c o m / r e a d / 2018 / 08 / 24 / 13494461 / j a d i-t e r s a n g k a-k p k-i d r u s-j u g a-m u n d u r-d a r i-~}$ kepengurusan-golkar. Jadi Tersangka KPK, Idrus Juga Mundur dari Kepengurusan Golkar.

18 https://www.merriam-webster.com/dictionary/mediocre Diakses pada Tanggal 14 November 2019 Pukul 22:22 WIB.

${ }^{19}$ Kominfo.go.id, Jadikan Indonesia Mandiri, Berkepribadian, dan Berdaulat, (edisi 18 Agustus 2015) Diakses Tanggal 8 Juni 2020 Pukul 09"12 WIB. 
fiskal dalam rencana kerja yang berupa kerangka regulasi dan kerangka pendanaan yang bersifat indikatif. ${ }^{20}$

Menteri dituntut untuk menunjukkan kinerja yang baik dalam penugasannya sehingga dibutuhkan kinerja yang nyata dan kerja keras dalam memperbaiki berbagai kondisi Indonesia. Sebagai contoh nyata yaitu ketika Presiden Jokowi menjadi sasaran kritik sejumlah pihak lantaran mempersilahkan sejumlah menterinya rangkap jabatan. Hal ini berbeda dengan komitmen yang ia tegaskan ketika baru terpilih menjadi Presiden pada tahun 2014, bahwa menteri tidak boleh merangkap jabatan sebagai ketua umum atau pejabat struktural partai politik. ${ }^{21}$ Sehingga hal ini akan mempengaruhi terhadap kinerja dan fokus para menteri tersebut dalam menjalankan tugasnya.

Beberapa kasus di atas mencuat di kalangan masyarakat yang melahirkan kekhawatiran terhadap kinerja pemerintah ke depannya. Seperti ketika diteliti lebih mendalam perihal susunan kabinetnya masih melibatkan menteri yang terindikasi dalam kasus korupsi sebagaimana yang dilaporkan oleh Gerakan Dekrit Rakyat Indonesia dan Koalisi Masyarakat Sipil ke Komisi Pemberantasan Korupsi (KPK) yang mencatat beberapa nama menteri yang terindikasi kasus korupsi. Hal ini terbukti dengan adanya menteri yang terlibat di dalam kasus korupsi seperti yang disebutkan diatas, sehingga diberhentikan di tengah jalan, hal ini sangat memberikan pukulan telak terhadap Presiden.

Tercatat dalam kepemerintahan Jokowi-JK terjadi defisit perdagangan, yang disebabkan kinerja neraca non migas yang memburuk. Pada 2014 mencatat, posisinya berada di kisaran 11,2 miliar dollar AS Dan terus meningkat sampai 2017 di angka 20,4 dollar AS. Ajaibnya angka itu terjun bebas pada 2018 menjadi hanya 4 miliar dolar AS. Penyebab defisit neraca dagang indonesia memang tak tunggal. Salah satunya disebabkan kondisi perekonomian global yang melambat dan carut-marut moneter Indonesia pada tahun itu, tak dapat dipungkiri bila selama 2018 banyak drama ego sektoral antar-kementerian teknis di bawah koordinasi Menteri Koordinator Bidang Perekonomian, Darmian Nasution.

Terdapat sejumlah gugatan kepada pemerintah Jokowi yang berakhir kemenangan bagi kelompok masyarakat, rakyat menggugat karena kebijakan pemerintah bertolak belakang dengan kepentingan publik. Selama Jokowi memimpin Indonesia. Setidaknya ada tiga gugatan penting yang dimenangkan rakyat. Ketiganya adalah gugatan citizen law suit kebakaran hutan dan lahan (karhutla) di Kalimantan Tengah; pemutusan jaringan internet di Provinsi Papua dan Provinsi Papua Barat pada tahun 2019 uji materi Perpres 75/2019 dan tentang BPJS Kesehatan, namun untuk BPJS ini sudah memasuki periode ke-dua dalam masa pemerintahan Jokowi.

Selain catatan buruk kinerja pemerintahan Jokowi diatas. Komisi Untuk Orang Hilang dan Korban Tindak Kekerasan [KontraS] kembali mengeluarkan laporan evaluasi atas kinerja pemerintahan Joko Widodo - Jusuf Kalla: Kabinet Indonesia Kerja yang tepat menginjak 4 tahun kepemimpinannya pada tanggal 20 Oktober 2018. Setiap tahunnya, KontraS merilis evaluasi kinerja pemerintahan yang sedang memimpin, khususnya di sektor penegakan hak asasi manusia. Laporan penilaian atas kinerja pemerintahan Joko Widodo- Jusuf Kalla (Jokowi-Kalla) di sektor hak asasi manusia (HAM) ini disusun KontraS dalam wujud analisis

${ }^{20}$ Rahmi Jened, Teori dan Kebijakan Hukum Investasi Langsung (Direct Investment), (Jakarta: Kencana, 2016), 96.

${ }^{21}$ https;//amp.kompas.com/lifestyle/read/2018/01/22/22215911/menteri-rangkap-jabatan-disarankantunjukkan-kinerja-demi-citra-jokowi, diakses pada tanggal 16 November 2019 pukul 23;23 WIB. 
ketimpangan (gap analysis) antara janji serta komitmen HAM Jokowi-Kalla dengan realisasinya hingga akhir tahun keempat periode pemerintahan. Indikator yang digunakan adalah komitmen HAM pemerintahan Jokowi-Kalla sebagaimana termuat dalam dokumen visi dan misi, program prioritas calon Presiden dan Wakil Presiden tahun 2014, hal itu menjadi dokumen resmi yang disampaikan kepada Komisi Pemilihan Umum dan publik. Sementara itu, dari 164 rekomendasi Universal Periodic Review (UPR) yang diakomodasi oleh Pemerintah RI, tujuh isu utama gagal dijalankan dan mengalami kemunduran, diantaranya agenda penghapusan impunitas, penuntasan kasus masa lalu, penghilangan paksa, penghapusan dan pencegahan praktik penyiksaan, penghapusan hukuman mati, Jaminan HAM dalam penindakan tindak pidana terorisme, pelindungan pembela HAM dan jurnalis, penghormatan dan jaminan HAM di Papua, dan kebebasan fundamental lainnya.

Satu diantara 9 (sembilan) poin nawacita yang dirumuskan oleh Jokowi-Jusuf Kalla sebagai janji kampanye pada pemilihan presiden dan wakil presiden di tahun 2014 yang lalu, adalah peningkatan kesejahteraan masyarakat khususnya dengan mendorong reforma agraria atau land reform secara menyeluruh. Mekanisme reforma agraria di Indonesia bersandar pada Tap MPR No IX/2001 tentang Pembaruan Agraria dan Pengelolaan Sumber Daya Alam, Undang-Undang Nomor 5 tahun 1960 tentang pokok-pokok agraria dan Undang-Undang Dasar 1945. Lebih lanjut reforma agraria di Indonesia menghadapi banyak persoalan dan tantangan. Di antaranya seperti pergeseran politik pertanahan ke arah liberalisasi pertanahan berdasarkan kebutuhan industri, regulasi yang tumpang tindih baik secara horizontal maupun vertikal, tata ruang wilayah yang belum memadai, timbulnya konflik agraria dan krisis ekologi.

Sementara itu, atas nama memerangi hoax, ujaran kebencian dan bentuk-bentuk politisasi identitas, pemerintah cenderung menggunakan cara-cara otoriter dengan memperluas sasaran kriminalisasi melalui pemberlakuan UU ITE, pelarangan kegiatan dan bentuk-bentuk sensor lainnya. Data yang dirilis sendiri oleh Polri pada tahun 2017 mencatat 3325 kasus hate speech atau ujaran kebencian yang didominasi oleh penggunaan pasal penghinaan (1657 kasus), perbuatan tidak menyenangkan (1224 kasus) dan pencemaran nama baik (444) kasus. Dari data tersebut terlihat jelas bagaimana meluasnya kriminalisasi hate speech yang diakibatkan oleh kegagalan dalam memformulasikan konsep kejahatan ujaran kebencian (hate Speech) dan kejahatan berbasis kebencian lainnya (hate crime). Dampaknya, pemerintah dan pendukungnya menggunakan hate speech sebagai instrumen yang efektif untuk membungkam kritik dari lawan politik. ${ }^{22}$

Strategi pemerintah melalui pembuatan Undang-Undang, seperti UU Ormas dan kebijakan serta penegakan hukum yang eksesif justru kontra produktif dengan yang dicitacitakan. Cara pemerintah yang terlalu eksesif dan cenderung sewenang-wenang (arbitrary) dalam mengelola dissent, kritik dan politisasi identitas justru berdampak pada semakin menyusutnya (shrinking) ruang demokrasi dan memburuknya kondisi kebebasan berekspresi, berkumpul dan berserikat. Salah satu momok yang menjadi penyebab atas kondisi di atas diantaranya adalah rendahnya perhatian pemerintah untuk agenda-agenda HAM, atau dengan kata lain, HAM belum menjadi agenda prioritas pemerintah. Agenda-agenda HAM kalah prioritas dibanding obsesi pemerintah untuk mengenjot pembangunan infrastruktur. Selain itu, politik kompromis untuk menjaga stabilitas politik dan kekuasaan pemerintah dan

22 THC REVIEW, Evaluasi dan Agenda Pemerintahan Jokowi (2014-2024), (Jakarta: The Habibie Center, 2019), 75. 
sharing power antara Jokowi dengan figur dan faksi-faksi yang memiliki catatan buruk dan kurang memiliki keberpihakan atas agenda HAM menyebabkan pemerintah tersandera untuk mewujudkan janji-janji dan komitmen HAM Pemerintah. ${ }^{23}$

Beberapa formulasi diatas setidaknya mampu menggambarkan sebagian besar program nawacita dan bagaimana perjalanan para menteri yang mengemban tiap sektor pembagian tugasnya. Harapannya dengan adanya hal ini, penentuan menteri di bangku kabinet negara menjadi hal urgensi dalam suatu negara khususnya Indonesia sebab menyangkut nasib bangsa di masa depan yang mana hal itu berdampak langsung terhadap kesejahteraan rakyat.

\section{Kesimpulan}

Dalam proses penyusunan Kabinet Kerja Presiden Joko Widodo mengajukan namanama calon menterinya kepada Pusat Pelaporan dan Analisis Transaksi Keuangan (PPATK), Komisi Pemberantasan Korupsi (KPK) serta lembaga Komisi Nasional Hak Asasi Manusia dengan harapan para menteri dalam kabinet kerjanya bersih dari catatan merah (black track record) serta menghindarkan korupsi kementerian yang sebelumnya banyak terjerat kasus korupsi. Hal ini dilakukan agar masyarakat menjadi yakin dan percaya kepada pemerintah bahwa menteri yang dipilih oleh presiden adalah sosok yang bersih dan kompeten. Akan tetapi ketika diteliti lebih mendalam perihal susunan kabinet Jokowi-JK masih melibatkan menteri yang terindikasi dalam kasus korupsi sebagaimana yang dilaporkan oleh Gerakan Dekrit Rakyat Indonesia dan Koalisi Masyarakat Sipil ke Komisi Pemberantasan Korupsi (KPK) yang mencatat beberapa nama menteri yang terindikasi kasus korupsi. Ditinjau secara empiris bahwa, komposisi kabinet kerja terdiri dari 16 orang yang berangkat dari anggota partai politik aktif pendukung Pemerintah, terhitung telah mengalami perombakan kabinet hingga jilid III.

Sistem presidensial di Indonesia yang berdampingan dengan multipartai seakan membuat hak prerogatif presiden dalam mengangkat menteri tereduksi oleh dinamika koalisi partai pendukung pemerintah. Pasal 17 UUD NRI 1945 setelah perubahan serta UndangUndang No. 39 Tahun 2008 Tentang Kementerian Negara lebih umum hanya mengatur tentang kelembagaan kementerian Negara, tidak memperkuat hak prerogatif presiden dalam mengangkat menteri dalam sistem presidensial, sehingga hal ini tidak menutup kemungkinan akan terjadinya dampak medioker sehingga berdampak buruk terhadap kinerja di dalam pemerintahan. Sebagai bukti, dilaporkan oleh Gerakan Dekrit Rakyat Indonesia dan Koalisi Masyarakat Sipil ke Komisi Pemberantasan Korupsi (KPK) yang mencatat beberapa nama menteri yang terindikasi kasus korupsi dan beberapa persoalan lainnya. Dengan demikian di era Jokowi-JK akan menghambat Perpres Nomor 2 Tahun 2015 Tentang Rencana Pembangunan Jangka Menengah Nasional 2015-2019 untuk mewujudkan visi welfare state Negara Indonesia yang tertuang dalam Undang-Undang Nomor 17 Tahun 2007 Tentang Rencana Pembangunan Jangka Panjang (RPJP) Nasional.

\section{Daftar Pustaka}

\section{Buku}

Amiruddin \& Zainal Asikin. 2016. Pengantar Metode Penelitian Hukum. Depok: PTGrafindo Persada, 2016.

\footnotetext{
${ }^{23}$ Ibid., 76.
} 
Hardiansyah, Haris. 2010. Metode Penelitian Kualitatif. Jakarta: Salemba Humanika.

Jened, Rahmi. 2016. Teori dan Kebijakan Hukum Investasi Langsung (Direct Investment). Jakarta: Kencana.

Kishel, Ann-Marie. 2007. What Is Goverment?. United State: Lerner Publishing Group.

Soekanto, Soerjono. 1986. Pengantar Penelitian Hukum. Jakarta: UI Press, 1986.

Susanti, Dyah Octorina dan A'an Efendi. 2014. Penelitian Hukum (Legal Research). Jakarta: Sinar Grafika.

Syafiie, Inu Kencana. 2013. Ilmu Pemerintahan. Bandung: Mandar Maju.

THC REVIEW. 2019. Evaluasi dan Agenda Pemerintahan Jokowi (2014-2024). Jakarta: The Habibie Center.

\section{Jurnal}

Amin, Muryanto. 2011. Konsep Negara Kesejahteraan Dari Waktu Ke Waktu. Jurnal Politeia /volume 3 Nomor 2.

Istigfaro, dkk. 2016. Relasi Pembantu Presiden Dalam Kabinet Kerja Jokowi-JK. Jurnal Penelitian Hukum Volume 3 Nomor 1.

Lol, Mikael . 2016. Politisasi Kabinet Kerja Indonesia Hebat Jokowi-JK, Jurnal Ilmu Sosial dan Ilmu Politik, Volume, 5 Nomer 1.

\section{Laman}

(http://nasional.kompas.com/read/2014/1026/18101431/ Ini.15.Menteri. Jokowi yang .Berasal dari. Partai. Politik.) tanggal akses 10/11/2019.

httpp://news.detik.com/read/2014/10/26/174034/2729927/10/ini-susunan-lengkap-kabinet-

kerja-jokowi-jk, Ini susunan lengkap Kabinet Kerja Jokowi, DetikNews. 26 Oktober 2014.

Diakses Tanggal Rabu, 1 April 2020 Pulul 11:00 WIB.

https://nasional.kompas.com/read/2018/08/14/13231311/tak-ingin-jadi-beban-presiden-jokowiasman-abnur-ingin-mundur-dari-kabinet Diakses pada Tanggal Selasa, 21 April 2020 Pukul 10:09 WIB.

https://nasional.kompas.com/read/2018/08/24/13494461/jadi-tersangka-kpk-idrus-jugamundur-dari-kepengurusan-golkar. Jadi Tersangka KPK, Idrus Juga Mundur dari Kepengurusan Golkar.

https://www.merriam-webster.com/dictionary/mediocre Diakses pada Tanggal 14 November 2019 Pukul 22:22 WIB.

https;//amp.kompas.com/lifestyle/read/2018/01/22/22215911/menteri-rangkap-jabatandisarankan-tunjukkan-kinerja-demi-citra-jokowi, diakses pada tanggal 16 November 2019 pukul 23:23 WIB.

Istman M.P. 2016. Presiden Jokowi Berhentikan Arcandra sebagai Menteri ESDM. Tempo.com. Diakses Tanggal Selasa, 21 April 2020 Pukul 10:01 WIB.

Kementerian Komunikasi dan Informatika Republik Indonesia. Siang Ini dilantik, Menteri Baru Langsung Ikut Sidang Kabinet Perdana, diakses tanggal Kamis, 21 Mei 2020 Pukul 11:18 WIB.

Kominfo.go.id, Jadikan Indonesia Mandiri, Berkepribadian, dan Berdaulat, (edisi 18 Agustus 2015) Diakses Tanggal 8 Juni 2020 Pukul 09"12 WIB.

\section{Perundang-undangan}

Undang-Undang Nomor 25 Tahun 2004 tentang Sistem Perencanaan Pembangunan Nasional, Rencana Pembangunan Jangka Panjang Nasional. 